Crop Breeding and Applied Biotechnology 14: 244-250, 2014

Brazilian Society of Plant Breeding. Printed in Brazil

\title{
ARTICLE
}

http://dx.doi.org/10.1590/1984-70332014v14n4a38

\section{Resistance of Eucalyptus pellita to rust (Puccinia psidii)}

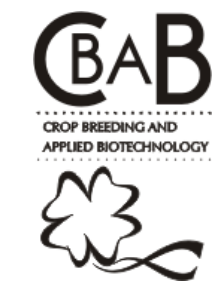

Marisângela Rodrigues Santos ${ }^{1}$, Lúcio Mauro da Silva Guimarães ${ }^{1}$, Marcos Deon Vilela de Resende ${ }^{2}$, Leonardo Novaes Rosse $^{3}$, Karina Carnielli Zamprogno ${ }^{3}$ and Acelino Couto Alfenas ${ }^{1 *}$

Received 14 June 2013

Accepted 15 September 2014

\begin{abstract}
Eucalypts rust (Puccinia psidii) is currently one of the major diseases in commercial eucalypt plantations in Brazil. The primary method of disease control is the use of resistant genotypes, and, among the different species of Eucalyptus, E. pellita is indicated as a promising source of resistance. In this work, the genetic control of rust resistance in $\mathrm{E}$. pellita through inoculations under controlled conditions of 441 plants from four full-sibling families was studied. Inoculations were performed using the monopostular isolate UFV-2, race 1. All families tested segregated for rust resistance, and the number of resistant plants was higher than susceptible in all crosses. Inheritance models based on few genes did not fully explain the observed segregation patterns, and the narrow-sense heritability of rust resistance was estimated between $32.7 \%$ and $37.3 \%$. The results suggested that rust resistance in E. pellita is complex and is controlled by major-and minor-effect genes.
\end{abstract}

Key words: Genetic resistance, quantitative inheritance, heritability, disease.

\section{INTRODUCTION}

Eucalypts rust caused by Puccinia psidii Winter is currently one of the major diseases of this genus (Alfenas et al. 2009) and P. psidii has also been reported to infect more than 100 plant species, all belonging to the family Myrtaceae. The fungus is widely distributed in Central and South America (Glen et al. 2007) and globally with occurrences in Florida (Marlatt and Kimbrough 1979), California (Mellano 2006), Hawaii (Uchida et al. 2006), Japan (Kawanishi et al. 2009) and most recently in Australia where the disease was initially attributed to Uredo rangelii (Carnegie et al. 2010, Carnegie and Lidbetter 2012) and in China on rose apple trees Syzygium jambos (Zhuang and Wei 2011), and in the same host species in New Caledonia. Puccinia psidii infects the tender shoots of seedlings in the nursery and coppice in the field. The pathogen causes growth reductions, loss of apical dominance, necrosis, hypertrophy, mini-cankers and death of the growing shoot tips (Ferreira 1983). Moreover, fungal sporulation reduces photosynthesis, interfering with the translocation and consequently reducing yields (Alves et al. 2011a).

The large inter- and intra-specific genetic variability for rust resistance in eucalypts has allowed the selection of resistant clones, progeny and species for commercial planting (Dianese et al. 1984, Alfenas et al. 1997, Carvalho et al. 1998, Xavier et al. 2007). Rust resistance varies according to species and provenance. Some species such as E. tereticornis, E. resinifera, E. paniculata and E. pellita are particularly resistant to the disease (Guimarães et al. 2010a, Zauza et al. 2010). In addition to the selection of resistant genotypes, the genetic basis of this resistance has been described. Junghans et al. (2003a) studied the rust resistance inheritance in full-sibling families of $E$. grandis and found that most of the phenotypic variation of the defense response is controlled by a major-effect gene, named Ppr1 (Puccinia psidii resistance gene 1). Recently, the locus Ppr1 was placed on a genetic reference map of eucalypts in linkage group 3 and was validated in two unrelated families, confirming the hypothesis that Ppr 1 controls a great portion of the variation in rust resistance (Mamani et al. 2010). However, further studies, particularly in interspecific hybrids progenies indicated that the genetic control of rust resistance is complex (Teixeira et al. 2009, Alves et al. 2011b).

Since eucalypt plantations in Brazil are based mainly on E. grandis, E. urophylla and their hybrids, the search for

\footnotetext{
${ }^{1}$ Universidade Federal de Viçosa, Departamento de Fitopatologia/Bioagro, Campus Universitário, 36570-900, Viçosa, MG, Brazil. *E-mail: aalfenas@ufv.br

${ }^{2}$ Embrapa Florestas, Estrada da Ribeira, Km 111, 83.411-000, Colombo, PR, Brazil

${ }^{3}$ Veracel Celulose S.A., CP 23, Rodovia BA-275, km 24, 45.820-970, Eunápolis, BA, Brazil
} 
resistance genes in other species is a key strategy to expand the genetic basis of resistance and to breed plants with other genetic combinations. Recently, Guimarães et al. (2010a) selected E. pellita clones as promising resistance sources for several eucalypts diseases, including rust. Besides the rust, E. pellita has been shown as a potential source of resistance to other important diseases such as ceratocystis wilt (Ceratocystis fimbriata) and leaf blight (Calonectria pteridis) (Guimarães et al. 2010a). The objective of the present work was to identify the genetic basis of E. pellita rust resistance based on controlled $P$. psidii inoculations in four full-sibling families.

\section{MATERIAL AND METHODS}

\section{Plant Material}

The genetic control of E. pellita rust resistance was analyzed in 441 plants derived from four families, as follows: i) the selfing of parent PE40 (128 plants); ii) the cross between parents PE40 x PE18 (130 plants); iii) the cross between parents PE40 x PE47 (93 plants) and iv) the cross between parents PE40 x PE151 (90 plants). The parents were previously evaluated for rust resistance, where PE18, PE40, and PE151 were resistant and PE47 was susceptible (Guimarães et al. 2010a). In the phenotyping performed by Guimarães et al. (2010a), the clone PE40 was the most resistant, showing immunity reaction, PE151 showed hypersensitive reaction (HR) and PE18 presented HR with eventual presence of puntiform pustules. On the other hand, PE47 showed abundant sporulation being classified as susceptible.

\section{Inoculation}

Seedlings of each family were labeled and then transplanted in 2-L pots containing substrate (MecPlant ${ }^{\circledR}$ ) with $6 \mathrm{~kg} \mathrm{~m}^{-3}$ superphosphate and $3 \mathrm{~kg} \mathrm{~m}^{-3}$ Osmocote ${ }^{\circledR}$ (19-6-10). Thirty days after transplanting, the seedlings were inoculated with a suspension of a $2 \times 10^{4}$ urediniospore inoculum of the monopostular isolate UFV-2 of $P$. psidii race 1 , which is predominant in different regions of Brazil (Junghans et al. 2003a). The isolate was maintained on seedlings of rose apple (Syzygium jambos) by periodic reinoculations every 20 days. Inoculations were performed as described by Ruiz et al. (1989). After inoculation, the seedlings were maintained in an intermitent mist irrigation chamber at $25{ }^{\circ} \mathrm{C}$ in the dark for $24 \mathrm{~h}$ and then transferred to a growth chamber with a photoperiod of $12 \mathrm{~h}$ at a light intensity of $40 \mathrm{mmol} \mathrm{s}^{-1} \mathrm{~m}^{-2}$ and an average temperature of $22^{\circ} \mathrm{C}$. The inoculated rooted cuttings of the two E. urophylla clones $\mathrm{C} 1179$ (R) and C1183 (S) were used for comparison.

\section{Resistance assessment}

The disease severity was assessed at 12 and 20 days after inoculation on a 4-point scale (Junghans et al. 2003b) that represents four severity classes based on the pustule size: $\mathrm{S} 0=$ immunity or hypersensitivity reaction (HR) with flecks or necrotic spots; $\mathrm{S} 1=$ small pustules, diameter $<0.8$ $\mathrm{mm} ; \mathrm{S} 2=$ medium-sized pustules, diameter of $0.8-1.6$ $\mathrm{mm}$; and $\mathrm{S} 3$ = large pustules, diameter $>1.6 \mathrm{~mm}$. The $\mathrm{S} 0$ and $\mathrm{S} 1$ plants were considered resistant and the S2 and S3 plants were susceptible. The final phenotype was based on evaluation (12 or 20 days) that showed leaves with more abundant sporulation. After the evaluations the Mendelian assumptions of resistance segregation were tested by $\chi^{2}$ $(\mathrm{p} \leq 0.05)$ using different genetic models.

The plants were pruned and the new shoots were inoculated again, as described above, to confirm the results. Disease evaluation was based on the same grading scale and on the averaged infected leaf area. For evaluation of the leaf diseased area, two leaves per plant with representative pustules of the plant phenotype were scanned and processed using QUANT (Vale et al. 2003). In the second inoculation, 105 plants of the cross PE40 x PE40, 66 of PE40 x PE151, 85 of PE40 x PE47, and 76 of PE40 x PE18 were evaluated. The number of plants assessed in the second inoculation was lower than in the first because some of the plants died after pruning.

The genetic and phenotypic parameters were estimated using Mixed Linear Models (REML [Residual Maximum Likelihood] and BLUP [Best Linear Unbiased Prediction]) for the quantitative data analysis of the diseased leaf area. The following mixed model was used: $y=X r+Z a+e$, where $y$ is the data vector, $r$ is the vector of replication effects (assumed as fixed) added to the overall mean, $a$ is the vector of additive genetic effects (assumed as random), and $e$ is the error or residue vector (random). The capital letters represent the incidence matrices for these effects. Estimates of the variance components (by REML) and of the narrow-sense heritability were obtained after fitting the model for the experiments with the families using the program Selegen-Reml/Blup ${ }^{\circledR}$ (Resende 2002). The estimator $\hat{h}_{a}^{2}=\frac{\hat{\sigma}_{a}^{2}}{\hat{\sigma}_{a}^{2}+\hat{\sigma}_{e}^{2}}$ was used to compute the individual heritability in the narrow sense, where $\hat{\sigma}_{a}^{2}$ is the estimate of the additive genetic variance and $\hat{\sigma}_{e}^{2}$ is the estimated residual variance. The data were also subjected to repeatability analysis by measurements of the lesion area on two leaves per plant. The following mixed model was used: $y=X m+W p+e$, where $y$ is the data vector, $m$ is the vector of measurement effects (assumed as fixed) added to the overall mean, $p$ is the vector of permanent 
plant effects (genotypic effects + permanent environmental effects) (assumed as random), and $e$ is the error or residue vector (random). The capital letters represent the incidence matrices for these effects. The estimator $\hat{\rho}=\frac{\hat{\sigma}_{p}^{2}}{\hat{\sigma}_{p}^{2}+\hat{\sigma}_{e}^{2}}$ was used to compute the individual repeatability, where $\hat{\sigma}_{p}^{2}$ is the estimate of the permanent phenotypic variance between plants and $\hat{\sigma}_{e}^{2}$ is the estimated residual variance.

\section{RESULTS AND DISCUSSION}

The four progenies of E. pellita segregated for rust resistance. The number of resistant plants was always greater than the number of susceptible plants, even in the PE40 $\mathrm{x}$ PE47 cross involving the susceptible parent (PE47) (Table $1)$. This result corroborates the previous studies reporting E. pellita as a good source of rust resistance (Carvalho et al. 1998, Guimarães et al. 2010a, Zauza et al. 2010). The PE40 x PE18 family had the lowest genotypic value, i.e., the progeny derived from this cross had a higher frequency of resistant plants than the other three crosses evaluated and it is therefore the most suitable for the selection of rust-resistant plants (Table 1). The cross PE40 x PE47 yielded plants with lowest frequency of resistant plants, as it involved a susceptible parent and therefore had a higher genotypic value. A wide spectrum of rust reaction was found among the genotypes inoculated, as immunity (note S0 resistant), hypersensitivity reaction (HR) (S0 - resistant), HR followed by puntiform pustules ( $\mathrm{S} 1$ - resistant) and abundant sporulation on leaves (S2 and S3 - susceptible) and in petiole (S3 - susceptible). The comparators, clones C1179 (R) and C1183 (S), showed immune reaction (S0 - resistant) and abundant sporulation (S3 - susceptible), respectively.

Since eucalypts can be cloned, the fixation of genetic gains through the selection of a single superior plant is rapid (Fonseca et al. 2010). Thus, selection of rust-resistant clones based on the results of controlled inoculation can facilitate the use of genetic resistance in disease control. However, to ensure the long-term success and to simplify the selection of resistant progeny plants, the genetic control of the trait must be known for the transfer of resistance using controlled crosses. The inheritance of rust resistance in eucalypts, studied since the early 2000s (Junghans et al. 2003a, Teixeira et al. 2009, Rosado et al. 2010, Alves et al. 2011b), has shown different models to explain the segregation patterns. In the present study, we tested three models of the genetic control of resistance based on major-effect genes to explain the resistance segregation in progenies of $E$. pellita (Table 2).

In the first model rust resistance was considered to have a simple Mendelian inheritance controlled by a major-effect gene ("major gene"). According to this model and according to the phenotype of the parents (Guimarães et al. 2010a), PE18, PE40, and PE151 are heterozygous (Aa) and the susceptible parent PE47 homozygous recessive (aa) for the gene that controls resistance. In contrast to the report of Junghans et al. (2003a), this model did not explain the monogenic segregation patterns for E. grandis obtained in the present work. The selfing progeny from the parent PE40 was the best to fit the proposed model $(\mathrm{P}=30.7 \%)$. Two other families PE40 (R) x PE18 (R) and PE40 (R) x PE151 (R) also fitted a single gene hypothesis, but with very low probability, 5.4 and $11.3 \%$ respectively (Table 2 ). The deviations of the other family from the expected ratio were significant, thus excluding the hypothesis of a monogenic dominant control of the rust resistance trait in E. pellita.

In the second model the hypothesis of deleterious genes linked to the resistance genes interfering with the classic Mendelian segregation pattern was evaluated. According to this model, the parents PE18, PE40, and PE151 are heterozygous for resistance (Aa) whereas PE47 is recessive homozygous (aa); thus, the progeny plants that presented homozygous resistance gene would not be viable. By the Chi-square test, the deviations of two progeny (PE40 x PE18 and PE40 $\times$ PE47) from the expected ratio were significant, excluding this second hypothesis as well (Table 2).

Table 1. Genotypic values and plant classification of Eucalyptus pellita progeny for rust resistance (Puccinia psidii) based on a 4-point scale of damaged leaf area

\begin{tabular}{|c|c|c|c|c|c|c|c|c|c|c|c|}
\hline \multirow{3}{*}{ Family } & \multirow{3}{*}{$\mathbf{N}$} & \multicolumn{6}{|c|}{ Severity class $^{2}$} & \multicolumn{2}{|c|}{ Genotypic value } & \multicolumn{2}{|c|}{ Accuracy } \\
\hline & & \multicolumn{3}{|c|}{ Resistant } & \multicolumn{3}{|c|}{ Susceptible } & \multirow{2}{*}{$\begin{array}{l}\text { Grade } \\
\text { scale }^{2}\end{array}$} & \multirow{2}{*}{$\begin{array}{c}\text { Lesion area } \\
(\%)\end{array}$} & \multirow{2}{*}{$\begin{array}{c}\text { Grade } \\
\text { scale }^{2}\end{array}$} & \multirow{2}{*}{ Lesion area $(\%)$} \\
\hline & & So & S1 & $\%$ & $\mathbf{S 2}$ & $\mathbf{S 3}$ & $\%$ & & & & \\
\hline PE40 (R) x PE18 (R) ${ }^{1}$ & 130 & 66 & 41 & 82 & 14 & 9 & 18 & 0.30 & 0.21 & 0.84 & 0.83 \\
\hline PE40 (R) x PE40 (R) & 128 & 69 & 22 & 71 & 8 & 29 & 29 & 1.14 & 1.73 & 0.85 & 0.84 \\
\hline PE40 (R) x PE151 (R) & 90 & 44 & 17 & 68 & 10 & 19 & 32 & 0.89 & 0.48 & 0.83 & 0.83 \\
\hline PE40 (R) x PE47 (S) & 93 & 51 & 8 & 63 & 8 & 26 & 37 & 1.37 & 2.23 & 0.83 & 0.82 \\
\hline
\end{tabular}

${ }^{1}$ Phenotyping performed by Guimarães et al. (2010a). $\mathrm{R}=$ resistant; $\mathrm{S}=$ susceptible

${ }^{2}$ Classification based on a diagrammatic scale (Junghans et al. 2003b). 
Table 2. Fitting genetic models to rust (Puccinia psidii) resistance in Eucalyptus pellita

\begin{tabular}{|c|c|c|c|c|c|c|c|c|}
\hline \multicolumn{9}{|c|}{ Monogenic dominant model } \\
\hline \multirow[b]{2}{*}{ Progeny } & \multirow[b]{2}{*}{$\mathbf{N}$} & \multirow[b]{2}{*}{$\begin{array}{l}\text { Allele configura- } \\
\text { tion }\end{array}$} & \multicolumn{2}{|c|}{ Observed $^{2}$} & \multirow{2}{*}{$\begin{array}{c}\text { Expected } \\
\text { (R:S) }\end{array}$} & \multirow[b]{2}{*}{ Hypothesis } & \multirow[b]{2}{*}{$x^{2}$} & \multirow[b]{2}{*}{$\mathbf{P}(\%)$} \\
\hline & & & $\begin{array}{c}\mathrm{R} \\
(\mathrm{S} 0+\mathrm{S} 1) \\
\end{array}$ & $\begin{array}{c}\mathrm{S} \\
(\mathrm{S} 2+\mathrm{S3}) \\
\end{array}$ & & & & \\
\hline PE40 (R) x PE40 (R) & 128 & Aa $\mathrm{x} \mathrm{Aa}$ & 91 & 37 & $96: 32$ & $3: 1$ & 1.04 & 30.7 \\
\hline PE40 (R) x PE151 (R) & 90 & Aa $\mathrm{x}$ Aa & 61 & 29 & $67.5: 22.5$ & $3: 1$ & 2.50 & 11.3 \\
\hline \multicolumn{9}{|c|}{ Monogenic dominant model with lethal allele linked to the resistance gene } \\
\hline \multirow[b]{2}{*}{ Progeny } & \multirow[b]{2}{*}{$\mathbf{N}$} & \multirow[b]{2}{*}{$\begin{array}{c}\text { Allele configura- } \\
\text { tion }\end{array}$} & \multicolumn{2}{|c|}{ Observed $^{2}$} & Expected & \multirow[b]{2}{*}{ Hypothesis } & \multirow[b]{2}{*}{$\chi^{2}$} & \multirow[b]{2}{*}{$\mathbf{P}(\%)$} \\
\hline & & & $\begin{array}{c}R \\
(\mathrm{~S} 0+\mathrm{S} 1)\end{array}$ & $\begin{array}{c}\mathrm{S} \\
(\mathrm{S} 2+\mathrm{S} 3) \\
\end{array}$ & (R:S) & & & \\
\hline PE40 $\left(\mathrm{R}^{1}\right)$ x PE18 (R) & 130 & Aa $\times$ Aa & 107 & 23 & $86.7: 43.3$ & $2: 1$ & 14.3 & 0 \\
\hline \multicolumn{9}{|c|}{ Digenic dominant model } \\
\hline \multirow[b]{2}{*}{ Progeny } & \multirow[b]{2}{*}{$\mathbf{N}$} & \multirow[b]{2}{*}{$\begin{array}{l}\text { Allele configu- } \\
\text { ration }\end{array}$} & \multicolumn{2}{|c|}{ Observed $^{2}$} & Expected & \multirow[b]{2}{*}{ Hypothesis } & \multirow[b]{2}{*}{$\chi^{2}$} & \multirow[b]{2}{*}{$\mathbf{P}(\%)$} \\
\hline & & & $\begin{array}{c}\mathrm{R} \\
(\mathrm{S} 0)\end{array}$ & $\begin{array}{c}\mathrm{S} \\
(\mathrm{S} 1+\mathrm{S} 2+\mathrm{S3}) \\
\end{array}$ & (R:S) & & & \\
\hline PE40 (R) x PE18 (S3) & 130 & $\mathrm{AaBb} x$ aaBB & 66 & 64 & $65: 65$ & $1: 1$ & 1.58 & 86 \\
\hline PE40 (R) x PE40 (R) & 128 & $\mathrm{AaBb} \times \mathrm{AaBb}$ & 69 & 59 & $72: 56$ & $9: 7$ & 0.28 & 59.2 \\
\hline PE40 (R) x PE151 (R) & 90 & $\mathrm{AaBb} \times \mathrm{AaBb}$ & 44 & 46 & $50.6: 39.4$ & $9: 7$ & 1.98 & 15.9 \\
\hline PE40 (R) x PE47 (S) & 93 & $\mathrm{AaBb} \times \mathrm{aaBB}$ & 51 & 42 & $46.5: 46.5$ & $1: 1$ & 0.87 & 35 \\
\hline
\end{tabular}

${ }^{1}$ Phenotyping by Guimarães et al. (2010a). $\mathrm{R}$ = resistant; $\mathrm{S}=$ susceptible

${ }^{2}$ Classification based on a diagrammatic scale (Junghans et al., 2003b). S0 = immunity or hypersensitivity reaction $(\mathrm{HR})$ with flecks or necrotic spots; $\mathrm{S} 1=$ small pustules,

$<0.8 \mathrm{~mm}$ diameter; $\mathrm{S} 2=$ medium-sized pustules (diameter of $0.8-1.6 \mathrm{~mm}$ ); and $\mathrm{S} 3=$ large pustules $($ diameter $>1.6 \mathrm{~mm})$.

${ }^{3}$ This model the parent PE18 was considered susceptible to present small puntiform pustules (Note S1).

Table 3. Genetic parameters of rust resistance of Eucalyptus pellita progeny inoculated with Puccinia psidii.

\begin{tabular}{lcr}
\hline \multirow{2}{*}{ Genetic parameter } & & Value \\
\cline { 2 - 3 } General mean & Grade scale $^{1}$ & Damaged leaf area (\%) \\
Individual phenotypic variance & 0.85 & 0.96 \\
Genotypic variance in full-sibling progeny & 1.66 & 8.28 \\
Residual variance within plots & 0.31 & 1.35 \\
Individual narrow-sense heritability & 1.35 & 6.93 \\
Additive within-plot heritability & 0.37 & 0.32 \\
Accuracy of family selection & 0.23 & 0.19 \\
Repeatability & 0.99 & 0.96 \\
\hline
\end{tabular}

${ }^{1}$ Classification based on a diagrammatic scale (Junghans et al. 2003b).

In the third model the inheritance of rust resistance in E. pellita was assumed to be digenic. To test this model it was assumed that the resistant parents carry two genes in heterozigozity for the trait $(\mathrm{AaBb})$ and that the susceptible parent is recessive homozygous or heterozygous for one of the genes (aabb; A_bb or aaB_). However, this model was only possible when the S1 plants, as the parent PE18, previously classified as resistant (Guimarães et al. 2010a), were considered susceptible. This model fitted well to the expected segregation ratios in the four crosses (Table 2). The classification of the S1 plants as resistant follows Junghans et al. (2003b) for E. grandis. Although considered resistant, these plants present puntiform pustules. Thus, it is possible that the S1 plants have no major-effect resistance genes (major genes) but rather carry minor-effect genes, which retards or reduce fungal sporulation. In this case, despite 
being an accepted model, it was assumed that minor-effect genes affect significantly the resistance response, leading to deviations from the expected segregation patterns of one or few genes. Other inheritance models based on few genes were also tested without success (data not shown). Despite the absence of a single inheritance model that would explain the obtained segregation patterns without exception, the high number of resistant plants suggests the involvement of major genes in rust resistance control (Figure 1), thus making it more plausible to consider rust resistance in $E$. pellita as a complex trait controlled by genes of major and minor effects.

To demonstrate the role of minor-effect genes in the rust resistance of E. pellita, different genetic parameters of the progeny were estimated (Table 3 ). The narrow-sense heritability of rust resistance was estimated at $37.3 \%$, when evaluation of the disease was based on the rating scale (Junghans et al. 2003b) and at $32.7 \%$ on the infected leaf area. In both cases the heritability was found to be moderate, reinforcing the hypothesis that polygenes act in response to rust resistance in E. pellita. The values were similar to those reported by Pinto et al. (2014) for rust resistance in E. dunnii progenies under controlled environment. The repeatability coefficient was estimated at $92 \%$, which represents the highest limit that the broad-sense heritability can achieve.
Considering a possible low permanent environmental effect on the character, it can be inferred that the broad-sense heritability is high. Due to the large difference between the two heritability values, it can also be inferred that the character has high allelic dominance and, or epistasis. Discrepant heritability estimates in the broad and narrow sense were also reported by Guimarães et al. (2010b) in the pathosystem Eucalyptus-canker (Chrysoporthe cubensis) in E. grandis $\mathrm{x}$ E. urophylla hybrid progeny inoculated under field conditions.

The accuracy values found in the present study were high (Table 3). According to Resende (1995), a greater selection accuracy results in higher accuracy and therefore a greater genetic gain. The repeatability coefficient found in this study was $92 \%$ for the analyses of the mean percentage data of the infected leaf area (Table 3), with an accuracy of $96 \%$. These results indicated that a single leaf is sufficient to quantify the lesioned area using the program Quant. Alves et al. (2011b) obtained a repeatability coefficient of $84.5 \%$ compared to two different disease assessments on a rating scale (Junghans et al. 2003b) of the same progeny. Our results demonstrate the effectiveness of the inoculation and the method of assessment using either a grading scale or diseased leaf area for the selection of rust-resistant plants.

This is the first study regarding the inheritance of rust

\section{PE40XPE40}

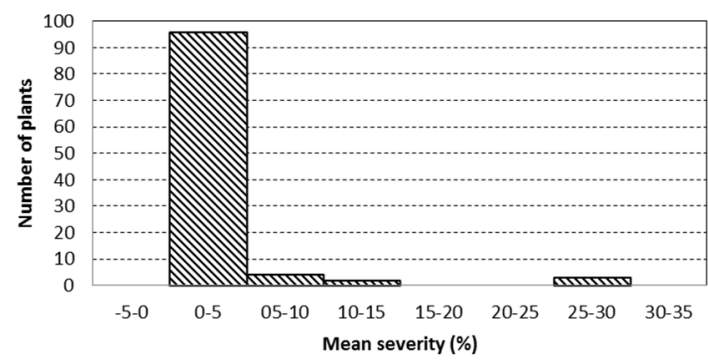

PE40XPE47

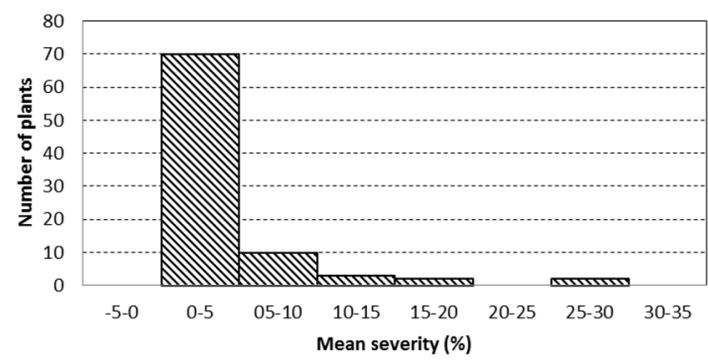

PE40xPE151

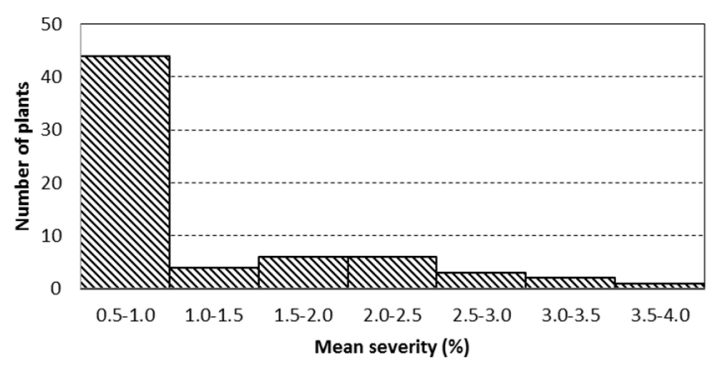

PE40xPE18

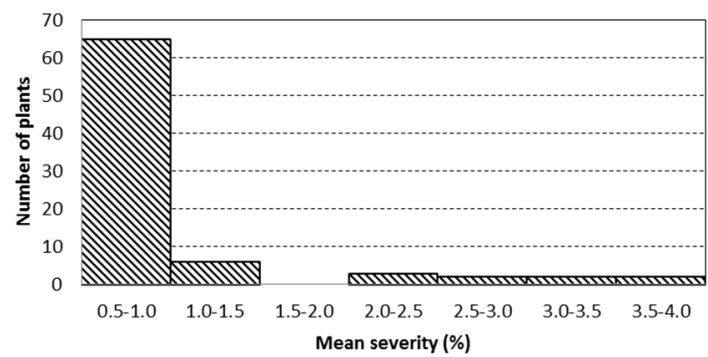

Figure 1. Frequency distribution of plants per progeny based on the mean percentage of lesioned leaf area of Eucalyptus pellita families inoculated with Puccinia psidii. 
resistance in E. pellita. Considering that the inheritance models of resistance based on one or two genes do not satisfactorily explain our results and that the moderate heritability values found in this work indicate the involvement of polygenes in the plant defense response, it is believed that rust-resistance in E. pellita is controlled by major- and minor-effect genes (major and minor genes). A similar inheritance model, involving genes controlling qualitative and quantitative trait, has been demonstrated for the pathosystem Melampsora-Populus (Bresson et al. 2011). Moreover, these results are consistent with the hypothesis that much of the resistance is controlled by a major-effect gene, for example by Ppr-1 in E. grandis (Junghans et al. 2003a) and with the findings of Alves et al. (2011b) who suggested the presence of major- and minor-effect genes that control resistance. The understanding that both major and minor genes are involved in the defense response of Eucalyptus spp. to rust reveals the complexity of the host-pathogen interaction and helps explain the success achieved in the cloning and selection of resistant plants, whereby all additive and non-additive effects are easily captured.

\section{ACKNOWLEDGEMENTS}

The authors are indebted to the Conselho Nacional de Desenvolvimento Científico e Tecnológico (CNPq), the Fundação de Amparo à Pesquisa do Estado de Minas Gerais (FAPEMIG), and Veracel SA for funding this work. The authors wish to thank Veracel SA for providing the progeny plants and are particularly indebted to Sezar Augusto, Bruno Vasconcelos Amaral Rodrigues, Douglas Lau, and Alexandre Alonso Alves for their valuable contributions to this work.

\section{Resistência à ferrugem do eucalipto (Puccinia psidii) em Eucalyptus pellita}

Resumo - A ferrugem do eucalipto (Puccinia psidii) é atualmente uma das principais enfermidades em plantios comerciais de eucalipto no Brasil. Dentre as diferentes espécies de eucalipto, Eucalyptus pellita é apontada como uma promissora fonte de resistência. Neste trabalho estudou-se o controle genético da resistência à ferrugem em E. pellita por meio de inoculações em condições controladas de 441 plantas oriundas de quatro progênies. As inoculações foram realizadas com o isolado monopostular UFV-2, raça 1. Todas as progênies segregaram para resistência à ferrugem, sendo o número de plantas resistentes superior em todos os cruzamentos. Modelos de herança baseados em poucos genes não explicaram totalmente os padrões de segregação obtidos. A herdabilidade no sentido restrito da resistência à ferrugem foi estimada entre 32,7\% a 37,3\%. Os resultados obtidos sugerem que a resistência à ferrugem em E. pellita é complexa, sendo governada por genes de efeito maior e menor.

Palavras-chave: Resistência genética, herança quantitativa, herdabilidade, doença.

\section{REFERENCES}

Alfenas AC, Zauza EAV, Mafia RG and Assis TF (2009) Clonagem e doenças do eucalipto. $2^{\text {nd }}$ ed., Editora UFV, Viçosa, 500p.

Alfenas AC, Valle LAC, Xavier AA, Brommonschenkel SH, Grattapaglia D, Silva CC, Bertolucci FL and Penchel R (1997) Eucalyptus rust: genetic variability of elite clones and histological characterization of the resistance reaction. Conference on Silviculture and Improvement of Eucalypt 2: 60-64.

Alves AA, Guimarães LMG, Chaves ARM, Da Matta FM and Alfenas AC (2011a) Leaf gas exchange and chlorophyll a fluorescence of Eucalyptus urophylla in response to Puccinia psidii infection. Acta Physiologiae Plantarum 33: 1831-1839.

Alves AA, Rosado CCG, Faria DA, Guimarães LMG, Lau D, Brommonschenkel SH, Grattapaglia D and Alfenas AC (2011b) Genetic mapping provides evidence for the role of additive and nonadditive QTLs in the response of inter-specific hybrids of Eucalyptus to Puccinia psidii rust infection. Euphytica 183: 27-38.

Bresson A, Jorge V, Dowkiw A, Guerin V, Bourgait I, Tuskan GA, Schmutz J, Chalhoub B, Bastien C and Rampant PF (2011) Qualitative and quantitative resistances to leaf rust finely mapped within two nucleotide-binding site leucine-rich repeat (NBS-LRR)-rich genomic regions of chromosome 19 in poplar. New Phytologist 192: 151-163.
Carnegie AJ and Lidbetter JR (2012) Rapidly expanding host range for Puccinia psidii sensu lato in Australia. Australasian Plant Pathology 41: 13-29.

Carnegie AJ, Lidbetter JR, Walker J, Horwood MA, Tesoriero L, Glen M and Priest MJ (2010) Uredo rangelli, a taxon in the guava rust complex, newly recorded on Myrtaceae in Australia. Australasian Plant Pathology 39: 463-466.

Carvalho AO, Alfenas AC, Maffia LA and Carmo MGF (1998) Resistência de espécies, progênies e procedências de Eucalyptus à ferrugem, causada por Puccinia psidii Winter. Pesquisa Agropecuária Brasileira 33: 139-147.

Dianese JC, Moraes TSD and Silva AR (1984) Reponse of Eucalyptus species to field infection by Puccinia psidii. Plant Disease 68: 314-316.

Ferreira FA (1983) Ferrugem do eucalipto. Revista Árvore 7: 91-109.

Fonseca SM, Resende MDV, Alfenas AC, Guimarães LMS, Assis TF and Grattapaglia D (2010) Manual prático de melhoramento genético do eucalipto. Editora UFV, Viçosa, 200p.

Glen M, Alfenas AC, Zauza EAV, Wingfield MJ and Mohammed C (2007) Puccinia psidii: a threat to the Australian environment and economy - a review. Australasian Plant Pathology 36: 1-16.

Guimarães LMS, Titon M, Lau D, Rosse L, Oliveira LSS, Rosado CCG, 
MR Santos et al.

Christo GGO and Alfenas AC (2010a) Eucalyptus pellita as a source of resistance to rust, ceratocystis wilt and leaf blight. Crop Breeding and Applied Biotechnology 10: 124-131.

Guimarães LMS, Resende MDV, Lau D, Rosse LN, Alves AA and Alfenas AC (2010b) Genetic control of Eucalyptus urophylla and E. grandis resistance to canker caused by Chrysoporthe cubensis. Genetics and Molecular Biology 33: 525-531.

Junghans DT, Alfenas AC, Brommonschenkel SH, Oda S, Mello EJ and Grattapaglia D (2003a) Resistance to rust (Puccinia psidii Winter) in Eucalyptus: mode of inheritance and mapping of a major effect locus with RAPD markers. Theoretical Applied Genetics 108: 175-180.

Junghans DT, Alfenas AC and Maffia LA (2003b) Escala de notas para a quantificação da ferrugem do eucalipto. Fitopatologia Brasileira 28: $184-188$.

Kawanishi T, Uematsu S, Kakishima M, Kagiwada S, Hamamoto H, Horie H and Namba S (2009) First report of rust disease on ohia and the causal fungus, Puccinia psidii, in Japan. General Plant Pathology 75: 428-431.

Mamani EMC, Bueno NW, Faria DA, Guimarães LMS, Lau D, Alfenas AC and Grattapaglia D (2010) Positioning of the major locus for Puccinia psidii rust resistance (Ppr 1 ) on the Eucalyptus reference map and its validation across unrelated pedigrees. Tree Genetics $\&$ Genomes 6: 953-962.

Marlatt RB and Kimbrough JW (1979) Puccinia psidii on Pimento dioica in South Florida. Plant Disease 63: 510-512.

Mellano V (2006) Rust on myrtle found in San Diego county USDA. Retail Nursery Newsletter 1: 6 .

Pinto CS, Costa RML, Moraes C, Pieri C, Tambarussi V, Furtado E and Mori ES (2014) Genetic variability in progenies of Eucalyptus dunnii Maiden for resistance to Puccinia psidii. Crop Breeding and Applied Biotechnology 14: 187-193.
Resende MDV (2002) Genética biométrica e estatística no melhoramento de plantas perenes. Embrapa Informação Tecnológica, Brasília, 975p.

Resende MDV (1995) Delineamento de experimentos de seleção para maximização da acurácia seletiva e do progresso genético. Revista Árvore 19: 479-500.

Rosado TB, Tomaz RS, Ribeiro Junior MF, Rosado AM, Guimarães LMS, Araujo EF, Alfenas AC and Cruz CD (2010) Detection of QTL associated with rust resistance using IBD-based methodologies in exogamic Eucalyptus spp. populations. Crop Breeding and Applied Biotechnology 10: 321-328.

Ruiz RAR, Alfenas AC and Ferreira FA (1989) Influência de temperatura, luz e origem do inóculo sobre a produção de urediniosporos e teliosporos de Puccinia psidii. Fitopatologia Brasileira 14: 70-73.

Teixeira JEC, Guedes FTP, Dias DC, Bonine CAV and Camargo LEA (2009) Análise da herança da resistência a Puccinia psidii em progênies de híbridos interespecíficos de eucalipto avaliadas sob condições naturais de infecção. Tropical Plant Pathology 34: 203-210.

Uchida J, Zhong S and Killgore E (2006) First report of a rust disease on Ohia caused by Puccinia psidii in Hawaii. Plant Disease 90: 524.

Vale FXR, Fernandes Filho EI, Liberato JR (2003) QUANT: A software plant disease severity assessment. 8th International Congress of Plant Pathology 8: 105.

Xavier AA, Sanfuentes EV, Junghans DT and Alfenas AC (2007) Resistência de Eucalyptus globulus e Eucalyptus nitens à ferrugem (Puccinia psidii). Revista Árvore 31: 731-735.

Zauza EAV, Alfenas AC, Old K, Couto MMF, Graça RN and Maffia LA (2010) Myrtaceae species resistance to rust caused by Puccinia psidii. Australasian Plant Pathology 39: 406-411.

Zhuang J-Y and Wei S-X (2011) Additional materials for the rust flora of Hainan Province, China. Mycosystema 30: 853-860. 